\title{
Evaluation of New Cultivars of Fodder Cowpea in Terms of Growth Attributes and Seed Yield as Influenced by Various Doses and Varieties
}

\author{
Anjum Ahmad", Gajendra Singh Tomar, Sudhir Kumar Taunk and Nidhi Verma \\ Indira Gandhi Krishi Vishwa Vidyalaya, Raipur - 492 012, India \\ *Corresponding author
}

A B S T R A C T

\begin{tabular}{|l|}
\hline Ke y w o r d s \\
Cowpea, Growth \\
parameters, Seed \\
yield, Variety, \\
Phosphorus.
\end{tabular}

\section{Introduction}

The lack of sufficient quantity of green fodder throughout the year seems to be a major constraint in the growth of animal husbandry in India. This situation can be improved, if animals are fed with balance and adequate quantity and quality of feed and fodder (Singh and Singh, 2002).The area under fodder cultivation is only $4.4 \%$ of the total cultivated area. Chhattisgarh, the rice bowl of India, has a total livestock population of 12.9 millions, out of which majority of them are indigenous breeds (Anonymous, 2003). The productivity of animals in the state is quite low in comparison to other states of the country. Though, livestock rearing plays a significant role in the economy of Chhattisgarh, yet forage cultivation has remained almost neglected. According to the straw grain ratio of different crops grown, the total fodder production potential of all the crops has been estimated 6932 thousand tonnes for Chhattisgarh (Anonymous, 2006). The green fodder production is decreasing year after year. However, the estimated requirement for concentrate, green and dry fodder is 1250, 16848 and 15042 thousand tones respectively (Gupta and Kumar, 2007). The major part of livestock forage resources in the state is met either from by product (rice straw/crop residues) or from the less nutritious grasses 
leading to low production and productivity of livestock. Therefore, there is a need to boost the production of green and dry fodder from the available resources. Cowpea (Vigna unguiculata L. Walp.) has emerged out as a potential crop for meeting the requirement of high quality fodder to fast expanding cattle population.

Cowpea, popularly known as lobia, has substantial ability to fix atmospheric nitrogen and improves the soil fertility. The green fodder contains about 15-20 per cent crude protein and $50 \%$ digestible carbohydrate at the first stage of pod formation. The dualpurpose (fodder-cum-grain) cowpea varieties may enhance nutritional status of all classes of animals by providing quality green fodder and using cowpea seeds in the preparation of animal ration. India is the largest producer of cowpea in Asia, accounts for about $0.5 \mathrm{~m} \mathrm{t}$ production from an area of $1.5 \mathrm{~m}$ ha with an average grain and fodder yield of $3 \mathrm{q} \mathrm{ha}^{-1}$ and 25-45 $\mathrm{t} \mathrm{ha}^{-1}$ respectively.

Pulse crops require relatively higher quantity of phosphorus and are also sensitive to phosphorus deficiency. The key function of phosphorus is energy transfer and it takes part in all type of metabolism of plant. It is considered to be the most important nutrient for growth, better nodulation and higher nitrogen fixation of legumes like cowpea as reported by Rajshree and Pillai (2001). Nodulation and nitrogen fixation are also influenced by phosphatic fertilizers (Shukla and Yadav, 1982). The importance of phosphorus in the maintenance of the soil fertility and improving crop productivity is well recognized. There is ample evidence that indicates marked differences between cowpea genotypes and phosphorus uptake.Sairam et al., (1984) and Rajput and Singh (1996) reported that application of phosphorus improved the quality and fodder yields of cowpea. Besides phosphorus nutrition, variety or cultivar is also an important factor responsible for lower and high yield, which ultimately reflects the economics of the crop. Experiment carried out at Jabalpur (M.P.) with 8 cultivars of cowpea, (Agrawal et al., 2006) indicate that variety UPC-9202 produced significantly highest green fodder $\left(205.7 \mathrm{q} \mathrm{ha}^{-1}\right)$ and dry matter yields $(89.7 \mathrm{q}$ $\mathrm{ha}^{-1}$ ) over the rest of the cultivars. Therefore, the present investigation was conducted to evaluation of new cultivars of fodder cowpea in terms of growth attributes as influenced by various doses and varieties.

\section{Materials and Methods}

A field study was conducted at the Instructional farm of IGKV, Raipur during kharif season of 2008 to assess the production potential of different varieties of cowpea [Vigna unguiculata (L.) Walp.] under varying levels of phosphorus. The soil of the experimental plot was sandy loam in texture (Inceptisol) having pH 7.6 with low in organic carbon contents. Soil contains 182, 7.84 and $315 \mathrm{~kg} \mathrm{ha}^{-1}$ of available $\mathrm{N}, \mathrm{P}$ and $\mathrm{K}$, respectively at the time of sowing.

Crop received $435.2 \mathrm{~mm}$ rains during its growth period. Temperature and other weather conditions remained favorable for the growth and development of the crop. An experiment was laid down using factorial randomized design involving 18 treatments as six varieties of cowpea (viz. UPC-9202, UPC4200, UPC-626, UPC-628, UPC-629 and Bundel lobia-1and three levels of phosphorus (viz. 40, 60 and $80 \mathrm{~kg} \mathrm{P}_{2} \mathrm{O}_{5} \mathrm{ha}^{-1}$ ). Growth and yield parameters (plant height, no. of leaves, branches, nodules per plant, dry matter accumulation and seed yield) were observed in the field. Each treatment was replicated thrice resulting into a 54 plots. The seeds of cowpea varieties and phosphorus fertilizer were drilled in rows as per treatments on July $29^{\text {th }}, 2008$. 


\section{Plant height (cm)}

The plant height $(\mathrm{cm})$ was recorded at 20, 40, 60 and 90 DAS from five randomly selected plants. Height was measured in $\mathrm{cm}$ from ground surface to the top of node of main shoot. Mean height was then computed by dividing the summation by five.

\section{Number of leaves plant ${ }^{-1}$}

The number of leaves from five plants were counted at 20,40,60 and 90 DAS and averaged was worked out to get the number of leaves per plant.

\section{Number of branches plant ${ }^{-1}$}

Plants, which were taken into account for recording height, were also used to record number of branches. The number of branches of three plants were counted and averaged to get the number of branches per plant.

\section{Number of nodules plant ${ }^{-1}$}

The number of nodules per plant were recorded at 20, 40 and 90 DAS. Five plants were uprooted carefully and total number of nodules per plant were recorded.

\section{Dry matter accumulation, $\mathrm{g}$ plant $^{-1}$}

Five randomly selected plants, uprooted for nodules studies, were also used to record dry matter accumulation. Plants were initially air dried and then dried in hot air oven at $60^{\circ} \mathrm{C}$ for 48 hours. Then the oven dry biomass was weighed and averaged out to get dry matter accumulation in $\mathrm{g} \mathrm{plant}^{-1}$.

\section{Seed yield and stover yield}

One square meter plot was left for seed production at the time of cutting of forage cowpea at $50 \%$ flowering stage. The cowpea pods were hand-picked, dried and seeds were separated manually. The stover yield was worked out by subtracting the weight of seeds from the weight of total dry matter produce recorded prior to threshing. The seed and stover yield obtained from one square meter was converted in $\mathrm{kg}$ and $\mathrm{q} \mathrm{ha}^{-1}$ by multiplying the yield of respective plots with the hectare factor.

\section{Harvest index (HI)}

Harvest index was computed as the ratio of the seed yield to the biological yield and expressed in percentage.

Harvest index, \% = $\frac{\text { Seed yield }}{\text { Biological yield }}$

Where,

Biological yield $=$ Seed yield + Stover yield

\section{Results and Discussion}

\section{Growth parameters}

\section{Plant height (cm)}

Plant height of cowpea differed significantly under the influence of varieties and levels of phosphorus during all the growth periods, except at initial stage where plant height remained unaffected due to various treatments. Among the new varieties of cowpea, UPC-626 attained maximum height of 56.79 and $158.22 \mathrm{~cm}$ at 60 and 90 DAS being significantly higher compared to other varieties. Bundel lobia-1 produced shorter plants in comparison to new varieties of cowpea. The apparent variation in the plant height of different varieties might be due to their different growth behaviour. The inherent genetic make-up of the plant, which decides the biometric parameters, varies in each 
variety (Rajshree and Pillai, 2001). Plant height increased significantly with each successive increment up to $80 \mathrm{~kg}_{2} \mathrm{O}_{5} \mathrm{ha}^{-1}$ during all the stages of its growth. Higher dose of phosphorus (80 $\left.\quad \begin{array}{lllll}8 g & \mathrm{P}_{2} \mathrm{O}_{5} & \mathrm{ha}^{-1}\end{array}\right)$ produced taller plants measuring an average height of 50.98 and $135.89 \mathrm{~cm}$ during 60 and 90 DAS, respectively. This accounted for, an increase of 25.72 and 14.63 percent in the height of cowpea plants over lower dose of phosphorus (40 kg $\mathrm{P}_{2} \mathrm{O}_{5} \mathrm{ha}^{-1}$ ).

\section{Number of leaves plant ${ }^{-1}$}

Cowpea cv. UPC-626 produced maximum number of leaves during all the stages of growth and stands significantly superior over rest of the varieties with respect to leaf production.

The extent of increase in the number of leaves was in the order of 80.90 and $75.22 \%$ during 60 and 90 DAS, respectively over check (Bundel Lobia-1). The number of leaves per plant in general, was found to be reduced after 60 DAS. This might be because of leaf shedding due to senescence and maturity of the crop. Similar variation in leaf production was observed by Purushottam et al., (2001), they however indicated the superiority of UPC-953 in which maximum number of trifoliate leaves (16.8) per plant was observed. maximum number of leaves were produced under the application of $80 \mathrm{~kg} \mathrm{P}_{2} \mathrm{O}_{5} \mathrm{ha}^{-1}$ compared with lower dose of phosphorus. The higher level of phosphorus $\left(80 \mathrm{~kg} \mathrm{P}_{2} \mathrm{O}_{5} \mathrm{ha}^{-1}\right)$ recorded 27.37 and $24.85 \%$ more leaves at 60 and 90 DAS, respectively over lower levels of phosphorus application

\section{Number of branches plant ${ }^{-1}$}

Branching in cowpea proliferated remarkably from 20 to $60 \mathrm{DAS}$, followed by slight increase in branching during 60-90 DAS. The number of branches plant $^{-1}$ increased progressively during successive growth period of the crop up to 90 DAS under the influence of different treatments. Significantly higher number of branches plant ${ }^{-1}$ was recorded with cv. UPC-626 during all the growth periods. This cultivar produced maximum number of branches plant ${ }^{-1}(26.34$ $\%)$ at 60 DAS as compared to Bundel Lobia-1 which might be due to genetic variation in growth characteristics of different varieties (Bhatti et al., 1983). The results are in line with those reported by Tekleab et al., (2003).application of phosphorus at $80 \mathrm{~kg}$ $\mathrm{P}_{2} \mathrm{O}_{5} \mathrm{ha}^{-1}$ recorded the maximum number of branches plant $^{-1}$, which was significantly superior over reduced doses of phosphorus application. An increase of 38.51 and $26.76 \%$ was recorded at 60 and 90 DAS, respectively, with $80 \mathrm{~kg} \mathrm{P}_{2} \mathrm{O}_{5} \mathrm{ha}^{-1}$ over $40 \mathrm{~kg} \mathrm{P}_{2} \mathrm{O}_{5} \mathrm{ha}^{-1}$. Increasing levels of application of $\mathrm{P}$ increased the LAI and branching in legumes.

All the varieties of cowpea responded positively to the increasing doses of phosphorus. Variety UPC-626 gave maximum number of branches (5.94) plant $^{-1}$ at $80 \mathrm{~kg}$ $\mathrm{P}_{2} \mathrm{O}_{5}$ ha $^{-1}$ which was significantly higher than other treatment combinations.

\section{Number of nodules plant ${ }^{-1}$}

Nodules were small and elongate at initial stage of development and became bifurcate later on. The colour of nodule was light brown. The data indicated the positive impact of varieties and levels of phosphorus on nodulation of cowpea. As compared to variety Bundel lobia-1, all the varieties of cowpea bore significantly higher number of root nodules plant ${ }^{-1}$ during all the stages of crop growth. New variety UPC-626 superseded all other varieties with respect to maximum nodulation, as it contains 35.92 root nodules plant $^{-1}$ at 90 DAS, respectively. The variation in the nodulation among different varieties may be due their inherent genetic character. 
Application of phosphorus from $40-80 \mathrm{~kg}$ $\mathrm{P}_{2} \mathrm{O}_{5} \mathrm{ha}^{-1}$ enhanced the number of root nodules in cowpea during all the stages of crop growth. Phosphorus @ $80 \mathrm{~kg}_{2} \mathrm{O}_{5} \mathrm{ha}^{-1}$ produced significantly greater number of root nodules 31.18 plant $^{-1}$ at 90 DAS and these values was found to be significantly superior over lower doses of phosphorus application. Phosphorus when applied to legumes, enhances the activity of Rhizobia by increasing nodulation and thereby helps in fixing more atmospheric nitrogen. It may be concluded that increase in nitrogen fixation by cowpea crop as a result of phosphorus application is directly related with concurrent increase in the number of nodules. Other scientists (Sairem et al., 1985 and Indoria et al., 2005) also reported similar results.

Table.1 Seed yield $\left(\mathrm{kg} \mathrm{ha}^{-1}\right)$ of cowpea as influenced by variety and levels of phosphorus

\begin{tabular}{|l|c|c|c|c|}
\hline \multirow{2}{*}{ Variety } & \multicolumn{4}{|c|}{${\text { Levels of Phosphorus }\left(\mathbf{k g ~ h a}^{\mathbf{- 1}}\right)}$} \\
\cline { 2 - 5 } & $\mathbf{P}_{\mathbf{1}}(40)$ & $\mathbf{P}_{\mathbf{2}}(60)$ & $\mathbf{P}_{\mathbf{3}}(80)$ & Mean \\
\hline $\mathrm{V}_{1}(\mathrm{UPC}-\mathbf{9 2 0 2})$ & 120.52 & 172.29 & 154.95 & 149.25 \\
\hline $\mathrm{V}_{2}(\mathrm{UPC}-4200)$ & 120.39 & 147.73 & 141.39 & 136.50 \\
\hline $\mathrm{V}_{3}(\mathrm{UPC}-626)$ & 143.28 & 192.62 & 173.82 & 169.91 \\
\hline $\mathrm{V}_{4}(\mathrm{UPC}-628)$ & 126.62 & 155.62 & 148.83 & 143.69 \\
\hline $\mathrm{V}_{5}(\mathrm{UPC}-629)$ & 148.69 & 228.18 & 174.95 & 183.94 \\
\hline $\mathrm{V}_{6}($ Bundel lobia-1) & 112.19 & 134.41 & 125.52 & 124.04 \\
\hline Mean & $\mathbf{1 2 8 . 6 2}$ & $\mathbf{1 7 1 . 8 1}$ & $\mathbf{1 5 3 . 2 4}$ & \\
\hline & Variety & Phosphorus & Interaction & \\
\hline SEm $\mathbf{\pm}$ & $\mathbf{8 . 6 7 5}$ & $\mathbf{6 . 1 3 4}$ & $\mathbf{1 5 . 0 2}$ & \\
\hline CD $(\mathbf{5 \%})$ & $\mathbf{2 4 . 9 4 1}$ & $\mathbf{1 7 . 6 3 6}$ & NS & \\
\hline
\end{tabular}

Table. 2 Harvest index of cowpea as influenced by variety and levels of phosphorus

\begin{tabular}{|l|c|c|c|c|}
\hline \multirow{2}{*}{ Variety } & \multicolumn{4}{|c|}{ Levels of Phosphorus $\left(\mathbf{k g ~ h a}^{\mathbf{- 1}}\right)$} \\
\cline { 2 - 5 } & $\mathbf{P}_{\mathbf{1}}(40)$ & $\mathbf{P}_{\mathbf{2}}(60)$ & $\mathbf{P}_{\mathbf{3}}(80)$ & Mean \\
\hline $\mathbf{V}_{\mathbf{1}}$ (UPC-9202) & 5.19 & 6.37 & 4.86 & $\mathbf{5 . 4 7}$ \\
\hline $\mathbf{V}_{\mathbf{2}}$ (UPC-4200) & 4.48 & 4.33 & 3.18 & $\mathbf{3 . 9 9}$ \\
\hline $\mathbf{V}_{\mathbf{3}}$ (UPC-626) & 3.93 & 4.29 & 3.36 & $\mathbf{3 . 8 6}$ \\
\hline $\mathbf{V}_{\mathbf{4}}$ (UPC-628) & 4.82 & 4.98 & 3.59 & $\mathbf{4 . 4 6}$ \\
\hline $\mathbf{V}_{\mathbf{5}}$ (UPC-629) & 5.54 & 7.71 & 4.59 & $\mathbf{5 . 9 5}$ \\
\hline $\mathbf{V}_{\mathbf{6}}$ (Bundel lobia-1) & 5.31 & 5.17 & 4.44 & $\mathbf{4 . 9 7}$ \\
\hline Mean & $\mathbf{4 . 8 8}$ & $\mathbf{5 . 4 8}$ & $\mathbf{4 . 0 0}$ & \\
\hline & Variety & Phosphorus & Interaction & \\
\hline SEm \pm & $\mathbf{0 . 3 0 1}$ & $\mathbf{0 . 2 8 8}$ & $\mathbf{0 . 4 9 4}$ & \\
\hline CD $(\mathbf{5 \%})$ & $\mathbf{0 . 8 1}$ & $\mathbf{0 . 8 6 1}$ & NS & \\
\hline
\end{tabular}




\section{Int.J.Curr.Microbiol.App.Sci (2017) 6(10): 937-944}

Table.3 Plant height, no. of leaves, branches, nodulation, dry matter accumulation per plant as influenced by variety and levels of phosphorus at 60 and 90 DAT

\begin{tabular}{|c|c|c|c|c|c|c|c|c|c|c|}
\hline \multirow[t]{2}{*}{ Treatments } & \multicolumn{5}{|c|}{$60 \mathrm{DAT}$} & \multicolumn{5}{|c|}{$90 \mathrm{DAT}$} \\
\hline & $\begin{array}{l}\text { Plant } \\
\text { height }\end{array}$ & $\begin{array}{l}\text { No. of } \\
\text { leaves/pla } \\
n t\end{array}$ & $\begin{array}{l}\text { No. of } \\
\text { branches/pl } \\
\text { ant }\end{array}$ & $\begin{array}{l}\text { No. of } \\
\text { nodules/pla } \\
n t\end{array}$ & $\begin{array}{l}\text { DM } \\
\text { accumulation } \\
\text { /plant }\end{array}$ & $\begin{array}{l}\text { Plant } \\
\text { height }\end{array}$ & $\begin{array}{l}\text { No. of } \\
\text { leaves/pla } \\
n t\end{array}$ & $\begin{array}{l}\text { No. of } \\
\text { branches/plant }\end{array}$ & $\begin{array}{l}\text { No. of } \\
\text { nodules/pla } \\
\text { nt }\end{array}$ & $\begin{array}{l}\text { DM accumulation } \\
\text { /plant }\end{array}$ \\
\hline \multicolumn{11}{|l|}{ (A) Varieties } \\
\hline $\mathbf{V}_{\mathbf{1}}(\mathrm{UPC}-9202)$ & 39.50 & 70.51 & 4.57 & - & 18.42 & 108.66 & 60.44 & 4.66 & 20.20 & 19.97 \\
\hline $\mathbf{V}_{2}(\mathrm{UPC}-4200)$ & 49.92 & 82.66 & 4.14 & - & 18.21 & 116.33 & 76.03 & 4.27 & 27.09 & 20.03 \\
\hline $\mathbf{V}_{3}(\mathrm{UPC}-626)$ & 56.79 & 100.44 & 5.18 & - & 20.33 & 158.22 & 89.29 & 5.74 & 33.92 & 21.48 \\
\hline $\mathrm{V}_{4}(\mathrm{UPC}-628)$ & 48.69 & 81.18 & 4.37 & - & 18.72 & 152.33 & 75.92 & 4.40 & 26.44 & 19.86 \\
\hline $\mathbf{V}_{5}(\mathrm{UPC}-629)$ & 44.54 & 75.99 & 4.22 & - & 17.76 & 114.89 & 67.66 & 4.64 & 23.31 & 20.14 \\
\hline $\mathbf{V}_{6}$ (Bundel lobia-1) & 34.99 & 55.52 & 3.96 & - & 17.83 & 112.78 & 50.96 & 4.11 & 21.52 & 19.08 \\
\hline $\mathrm{SEm} \pm$ & 1.042 & 8.678 & 0.237 & - & 0.13 & 1.238 & 7.627 & 0.115 & 0.615 & 0.161 \\
\hline $\mathrm{CD}_{5 \%}$ & 2.995 & 24.95 & 0.682 & - & 0.41 & 3.559 & 21.928 & NS & 1.740 & 0.464 \\
\hline \multicolumn{11}{|c|}{ (B) Phosphorus $\left(\mathrm{kg} \mathrm{ha}^{-1}\right)$} \\
\hline $\mathrm{P}_{1}(40)$ & 40.55 & 68.94 & 3.48 & - & 17.39 & 118.55 & 62.77 & 4.11 & 20.67 & 19.06 \\
\hline $\mathrm{P}_{2}(60)$ & 45.69 & 76.40 & 4.36 & - & 18.43 & 110.17 & 69.01 & 4.50 & 23.40 & 19.89 \\
\hline $\mathrm{P}_{3}(80)$ & 50.98 & 87.81 & 4.82 & - & 19.55 & 135.89 & 78.37 & 5.21 & 28.18 & 20.78 \\
\hline SEm \pm & 0.737 & 6.136 & 0.168 & - & 0.09 & 0.875 & 5.39 & 0.212 & 0.416 & 0.114 \\
\hline $\mathrm{CD}$ at $5 \%$ & 2.118 & 19.44 & 0.482 & & 0.27 & 2.517 & 14.86 & 0.570 & 1.340 & 0.328 \\
\hline
\end{tabular}


Dry matter accumulation (DMA, g plant ${ }^{-1}$ )

Maximum dry matter were accumulated by cv. UPC-626 amounting to 20.33 and $21.48 \mathrm{~g}$ plant $^{-1}$ during 60 and 90 days stage of the crop and these values ranked significantly superior over other varieties. Taller plants coupled with more number of leaves and branches plant $^{-1}$, as stated in preceding sections, might have contributed towards more dry matter accumulation by UPC-626. Amongst different varieties, Bundel lobia-1 accumulated least amount of DM i.e. 17.83 and $19.08 \mathrm{~g} \mathrm{plant}^{-1}$ at 60 and 90 DAS. Similarly, variation in DMA in different varieties was also noticed by Diaz et al., (2002) at La Habana (Cuba).Dry matter accumulation at initial stage of crop growth remained unaffected due to phosphorus fertilization. Later on at 60 and 90 DAS, significant increase in DMA was noted with the application of successive doses of phosphorus. Compared to the lower doses of phosphorus, an increase of 19.55 and 20.78 $\mathrm{g}$ DMA plant ${ }^{-1}$ at 60 and 90 DAS respectively, was recorded when crop was fertilized with $80 \mathrm{~kg} \mathrm{P}_{2} \mathrm{O}_{5} \mathrm{ha}^{-1}$. Abundant supply of phosphorus promotes root and shoot growth, resulting higher amount of dry matter accumulation by an individual plant (Table 3 ).

\section{Seed yield $\left(\mathrm{kg} \mathrm{ha}^{-1}\right)$}

The data through indicated that seed yield varied significantly due to different varieties. Highest seed yield of $183.94 \mathrm{~kg} \mathrm{ha}^{-1}$ was recorded from UPC-629 closely followed by $169.91 \mathrm{~kg} \mathrm{ha}^{-1}$ from UPC-626. However, the differences between them were not marked significantly. Variety Bundel Lobia-1 was found to be significantly poor yielder as compared with all the varieties under study. While at Jhansi (U.P.) Bundel lobia-1 proved significantly superior over UPC-5287 in terms of seed yield attributes and seed yield (Kumar and Seth, 2004). Significant variation in seed yield among different varieties may probably be due to variation in the expression of growth and yield attributes. Increase in the levels of phosphorus from 40 to $60 \mathrm{~kg} \mathrm{P}_{2} \mathrm{O}_{5}$ $\mathrm{ha}^{-1}$ caused seed yield to increase from 128.62 to $171.81 \mathrm{~kg}^{-1}$, respectively and the differences between them were found to be significant. Gracy et al., (1998) also found maximum grain yield $\left(645 \mathrm{~kg} \mathrm{ha}^{-1}\right)$ with application of $60 \mathrm{~kg} \mathrm{P}_{2} \mathrm{O}_{5} \mathrm{ha}^{-1}$. Further increase in the dose of phosphorus was proved to be detrimental for seed production (Table 1).

\section{Harvest index (HI)}

Harvest index is a useful parameter to assess the translocation efficiency of crop plants. Data showed that harvest index was affected significantly due to varieties and levels of phosphorus (Table 2). The values of HI were found to be maximum $(5.95 \%)$ in cv. UPC629 which stand significantly higher than those recorded from other varieties. The HI was found to be lower in UPC-622 due to higher biological yields. It implies greater accumulation of dry matter in the seeds of UPC-629 compared with those of other varieties. Among the different levels of phosphorus fertilization, maximum harvest $(5.48 \%)$ was recorded under the application of $60 \mathrm{~kg} \mathrm{P}_{2} \mathrm{O}_{5} \mathrm{ha}^{-1}$, being significantly higher as compared to other levels of phosphorus, which might be due to better seed production from the crop fertilized with $60 \mathrm{~kg} \mathrm{P}_{2} \mathrm{O}_{5} \mathrm{ha}^{-1}$. Further increase in the level of phosphorus resulted considerable reduction in $\mathrm{HI}$ of cowpea due to production of higher amount of biomass.

\section{References}

Anonymous, 2003. $17^{\text {th }}$ Livestock Census, Dept. of Animal Husbandary, Govt. of India. (http://mospi.nic.in) accessed: $25^{\text {th }}$ July 2009.

Anonymous, 2006. Department of 
Agriculture, Government of Chhattisgarh

(http://agridept.cg.gov.in/default.htm) accessed: $20^{\text {th }}$ July 2009 .

Bhatti, M.B., 1983. Study on the effect of variety and seeding rate on growth characteristics and yield of fodder cowpea. Pak.J.Agri.Res, 4:116-119.

Diaz, M.F., Padilla, C.; Gonzalez, A. and Curbelo, F. 2002. Performance of grains and forages of three non-grouped maturity Vigna unguiculata varieties. Cuban Journal of Agricultural Science, 36 (1): 67-71.

Gupta, H.S., and Kumar, B. 2007. Feed and forage status for livestock in Chhattisgarh. Range Mgmt. \& Agroforestry, 28 (1): 6-9.

Kumar, D., and Seth, R. 2004. Seed yield response of fodder cowpea varieties to varying seed rate and seed size. Seed Research, 32 (2): 149-153.

Purushotham, S., Narayanswamy, G.V.; Siddaraju, R. and Girejesh, G.K. 2001. Production potential of fodder cowpea genotypes under rainfed conditions. Karnataka Journal of Agricultural
Sciences, 14 (2): 446-448

Rajasree, G., and Pillia, R.G. 2001. Performance of fodder legume under lime and phosphorus nutrition in summer rice fallows. Journal of Tropical Agriculture, 39: 67-70.

Rajput, A.L., and Singh, T.P. 1996. Response of nitrogen and phosphorus with and without rhizobium inoculation on fodder production of cowpea. Indian Journal of Agronomy, 41(1): 91-94.

Sairam, R.K., Tomer, P.S. and Ganguly, T.K. 1984. Growth, nitrogen uptake and forage yield of cowpea as affected by phosphorus application and inoculation. Agri. Sci. Digest, 4: 83-86.

Shukla, U.C., and Yadav, O.P. 1982. Effect of phosphorus and zinc on nodulation and nitrogen fixation in chickpea (Cicer arietinum L.). Plant and Soil, 65: 239249.

Tekleab, T., Agrawal, T.S. and Singh, Virendra. 2003. Study on the effect of variety and seeding rate on growth characteristics and yield of fodder cowpea. Legume Research, 26 (1): 4244.

\section{How to cite this article:}

Anjum Ahmad, Gajendra Singh Tomar, Sudhir Kumar Taunk and Nidhi Verma. 2017. Evaluation of New Cultivars of Fodder Cowpea in Terms of Growth Attributes and Seed Yield as Influenced by Various Doses and Varieties. Int.J.Curr.Microbiol.App.Sci. 6(10): 937-944. doi: https://doi.org/10.20546/ijcmas.2017.610.112 